\title{
Cluster Analysis of Non-conserved Proteins of Trypanosoma cruzi Reference Strains Displays Parity between these Groupings (Peptidemes) and the Consensually Accepted Parasite Lineages
}

\author{
Felipe S. COELHO', Danielle P. VIEIRA², Angela H. LOPES ${ }^{1}$, Maria A. SOUSA ${ }^{3}$ \\ ${ }^{1}$ Instituto de Microbiologia Paulo de Góes, Universidade Federal do Rio de Janeiro, RJ, Brasil \\ ${ }^{2}$ Polo Avançado da Universidade Federal do Rio de Janeiro, Macaé, RJ, Brasil \\ ${ }^{3}$ Laboratório de Toxoplasmose e Outras Protozooses, Instituto Oswaldo Cruz, Fiocruz, Rio de Janeiro, RJ, Brasil
}

\begin{abstract}
The protein profiles of the epimastigote stages from eight reference strains of Trypanosoma cruzi belonging to three different lineages (TcI, TcII and TcVI) were analyzed by SDS-PAGE (sodium dodecyl sulphate-polyacrylamide gel electrophoresis), under standardized conditions. More than 40 protein bands were observed in each strain. Around 55\% of them were not shared by all stocks (non-conserved proteins), representing their intra-specific variability. Then, they were coded for processing by numerical taxonomy, using three association coefficients and the UPGMA clustering algorithm. With all coefficients assayed, two major groups were clearly seen, confirming the dichotomy within T. cruzi taxon, as demonstrated by other molecular and biochemical approaches. In the present study, the term peptideme was used to name the groups of strains based on their polypeptide profiles, following the above-cited methodology. Then, two major peptidemes were identified, each one presenting subdivisions. The isolates identified as TcI clustered in the same major peptideme, displaying a subgroup with the opossum isolates (G, SC28, Dm28c) apart from the stock of human origin (Colombian strain). The other major peptideme also showed two subgroups, regardless the coefficient used. One of them included the TcII strains (Y, SF21), both from Brazilian patients, and the other the TcVI stocks, both originally from triatomines from Southern Brazil (CL Brener, FL). As far we know, this is the first report on the parity between the T. cruzi lineages consensually accepted and their grouping into peptidemes based on SDS-PAGE and the numerical analysis of non-conserved proteins.
\end{abstract}

Key words: Trypanosoma cruzi lineages, reference strains, SDS-PAGE analysis, numerical taxonomy, peptidemes

\section{INTRODUCTION}

Trypanosoma cruzi Chagas, 1909 (Protozoa: Kinetoplastea, Trypanosomatidae) is the etiological agent of Chagas disease (American trypanosomiasis), mainly in

Address for correspondence: Maria Auxiliadora de Sousa, Laboratório de Toxoplasmose e Outras Protozooses, Instituto Oswaldo Cruz, Fiocruz, Avenida Brasil 4365, 21040-900 Rio de Janeiro, RJ, Brasil; E-mail: msousaa@ioc.fiocruz.br
Latin American countries, where it infects 6-7 millions of people (WHO 2019). In the last decades, $T$. cruzi infections have spread around the world due to the mobility of asymptomatic patients from endemic areas. Nowadays, Chagas disease has been considered an emergent global health problem (Tanowitz et al. 2011, WHO 2019). This parasite presents high intra-specific diversity and may cause distinct clinical forms. Accordingly, the typing of T. cruzi samples is of utmost importance (Zingales et al. 2009, 2012; Consentino and Agüero 2012). 
The identification of T. cruzi can be very easy, since its typical forms could be seen in Giemsa-stained preparations $(\times 1,000)$ (Sousa 1999, Oliveira et al. 2017). Otherwise, the intra-specific variability of $T$. cruzi can also be evaluated using classical morphological and biological approaches (e.g. Brener 1965, Andrade et al. 1974, Sousa 1999, Kikuchi et al. 2010). However, the increasing development of biochemical and molecular techniques in the study of T. cruzi has substantially improved our knowledge on its identification, besides genomic and proteomic diversity. At present, at least six lineages (TcI-TcVI), previously named DTUs (discrete typing units) (Brisse et al. 2000), have been consensually accepted within $T$. cruzi taxon (Zingales et al. 2009, 2012). Another T. cruzi genotype (Tcbat) was described by Marcili et al. (2009), and has been confirmed by other authors (e.g. Consentino and Agüero 2012, Lima et al. 2015). These genetic types can be identified using several techniques, among them, the classical isoenzyme analyses (Miles et al. 1978), which gave us the first irrefutable evidences on the six DTUs in T. cruzi (Tibayrenc and Ayala 1988). Several genomic techniques have been employed to identify and to type $T$. cruzi stocks, among them the analyses of the restriction fragment length polymorphism (RFLP), followed by molecular hybridizations (Morel et al. 1980, Macedo et al. 1993). It was of utmost importance the implantation of the polymerase chain reaction (PCR) (Sturm et al. 1989, Fernandes et al. 2001) for identification and characterization of $T$. cruzi strains, as well as for diagnostic use. For improving the PCR results, the products can be subsequently sequenced, treated with restriction enzymes (PCR-RFLP), besides submitted to others amplifications, sometimes with several primers (e.g. Brito et al. 2008, Luna-Marín et al. 2009, Consentino and Agüero 2012, Zingales et al. 2012). Modified versions of the PCR, using combinations with other technologies, have also allowed valuable contributions to the clinical and epidemiological researches, as well as to basic studies (Cura et al. 2015). However, the majority of the above-cited techniques can be very expensive and usually restricted to specialized laboratories. There are also several biochemical techniques for identification of proteins expressed by distinct living beings. Some of them are very complex and applied in proteomic analyses, usually addressed to questions of clinical interest. However, in the last decades, proteomic analyses have also been used in more advanced studies for characterization and typing of several trypanosomatid species (e.g. El-Sayed et al. 2005, Kikuchi et al. 2010, Avila et al. 2016, Oliveira et al. 2018).
The analysis of the whole-proteins using one dimensional (1 D) sodium dodecyl sulphate-polyacrylamide gel electrophoresis (SDS-PAGE) (Laemmli 1970) is a very simple and low expensive analytical technique with a good resolving power (Gibson et al. 1978, Janssen and Van Bijsterveld 1981, Rosa et al. 2000). SDS-PAGE with adaptations, or associated to Western blotting, has been frequently used in study of trypanosomatids to identify specific proteins or antigens, searching for answers to biological and taxonomic questions, as well as to improve the diagnosis of organisms of medical interest (e.g. Contreras et al. 1985; Pinho and Giovanni-de-Simone 1989; Saldaña et al. 1993, 1998; Branquinha et al. 1995; Mejía et al. 2004; Ziccardi et al. 2005; Añez-Rojas et al. 2006; Gomes et at. 2008; Moraes et al. 2008; Cervantes-Landín et al. 2014).

Taylor and Williams (1977) and Taylor et al. (1982, 1983) used SDS-PAGE for distinguishing some Trypanosome species and their variants, including $T$. cruzi. Taylor et al. (1983) presented an excellent visualization of the SDS-PAGE profiles of three T. cruzi stocks belonging to different zymodemes (nowadays identified as TcI, II and IV), thus displaying protein bands with possible diagnostic value. However, in the same study, they analyzed several other T. cruzi isolates, and using subjective criteria proposed their classification into five peptidemes (subpopulations having similar polypeptide profiles), which displayed an incomprehensible correlation with their zymodemes.

In the present study, the whole-protein extracts of epimastigotes (in exponential growing phase) from eight reference strains of $T$. cruzi belonging to TcI, TcII and TcVI lineages, were analyzed by 1 D SDS-PAGE. As this technique generates complex banding patterns, we selected those protein bands not shared by all stocks (not-conserved proteins) to be coded and analyzed by numerical taxonomy procedures (Sneath and Sokal 1962). Interestingly, we could evidence strong correlations between the strain groups based on protein profiles (peptidemes) and their known lineages [DTUs, zymodemes $(Z)]$, according to the consensually accepted nomenclature (Zingales et al. 2009).

\section{MATERIALS AND METHODS}

Eight reference stocks of $T$. cruzi were used in the present work. These samples were from the trypanosomatid collection maintained by one of the authors (M. A. Sousa) at the Oswaldo Cruz Institute. They were identified by their names, code-numbers, original hosts and geographical origins, besides their phenotypic and genotypic classifications (see Table 1). 
Table 1. Trypanosoma cruzi reference stocks analyzed in the present study

\begin{tabular}{lllll}
\hline Stocks & CT-IOC* & Original hosts & Procedence** & Genetic types*** \\
\hline Y & 106 & Homo sapiens & Brazil (SP) & TcII (DTU 2a, Z2) \\
SF21 & 251 & Homo sapiens & Brazil (BA) & TcII (DTU 2a, Z2) \\
FL & 249 & Triatoma infestans & Brazil (RS) & TcVI (DTU 2e, ZB) \\
CL Brener & 005 & Triatoma infestans & Brazil (RS) & TcVI (DTU 2e, ZB) \\
Colombian & 004 & Homo sapiens & Colombia & TcI (DTU 1, Z1) \\
G & 216 & Didelphis sp. & Brazil (AM) & TcI (DTU 1, Z1) \\
Dm28c & 010 & Didelphis marsupialis & Venezuela & TcI (DTU 1, Z1) \\
SC28 & 350 & Didelphis aurita & Brazil (SC) & TcI (DTU 1, Z1) \\
\hline
\end{tabular}

* code-number of each stock in the Trypanosomatid Collection maintained by M. A. Sousa.

** Brazilian States: (SP) São Paulo, (BA) Bahia, (RS) Rio Grande do Sul, (AM) Amazônia, (SC) Santa Catarina.

*** In bold are the identifications of T. cruzi genetic types or lineage of each stock, as currently used (TcI-TcVI). In parentheses are their name in previous classifications: (DTU) discrete typing unit; (Z) zymodeme.

The analysis of $T$. cruzi strains were performed using (1-D) SDS-PAGE based on Laemmli (1970). Before analysis, all stocks had been maintained under standardized culture conditions, as follows. They were passed three times, at six-day intervals, in liver infusion tryptose (LIT) medium supplemented with brain heart infusion (BHI) and $10 \%$ fetal calf serum. Thereafter, exponential growing cells from 6 day-old cultures (epimastigote stages) were harvested and washed twice by centrifugation $(1,000 \times \mathrm{g}, 10 \mathrm{~min})$ in a phosphate-buffered saline (PBS), $\mathrm{pH}$ 7.2. The pellets were frozen in liquid nitrogen in a buffer containing $20 \mathrm{mM}$ Tris- $\mathrm{HCl}$ at $\mathrm{pH}$ 7.2. After twice freezing and defrosting, the cell pellets were resuspended in a lysis buffer $(20 \mathrm{mM} \mathrm{HCl}, 15 \mathrm{mM} \mathrm{NaCl}, 1 \mathrm{mM} \mathrm{Na} 3 \mathrm{VO} 4$, $1 \mathrm{mM}$ EDTA, $1 \mathrm{mM}$ EGTA, $10 \mathrm{mM} \mathrm{NaF}, 0.02 \%$ sodium azide; $\mathrm{pH}$ 8.0 ) with protease inhibitors and $1 \%$ SDS ( $\mathrm{pH} 7.2$ ). Subsequently, the suspensions were homogenized and centrifuged at $5,000 \times g$ for $10 \mathrm{~min}\left(4^{\circ} \mathrm{C}\right)$. Whole-cell protein extracts from the supernatant of each strain were dosed according to the Lowry' method (Lowry et al. 1951). Aliquots containing $60 \mu \mathrm{g}$ of the proteins from each stock were separated in $10 \%$ SDS-PAGE at $250 \mathrm{~V}$ and $25 \mathrm{~mA}$, for $90 \mathrm{~min}$, using a $16 \mathrm{~cm}$ high system (GE Healthcare Life Sciences). Molecular mass markers were also included in the gel. Coomassie brilliant blue was used for staining and visualization of the protein patterns. Those bands not shared by all stocks (twenty-two non-conserved proteins) were regarded the most representative of the variability in $T$. cruzi, then being selected for analysis according to numerical taxonomy principles (Sneath and Sokal 1962).

A data matrix was constructed with the eight strains of T. cru$z i$, these being "operational taxonomic units" (OTUs), and their selected bands, as "character units", with the records of presence (1) or absence (0) of each one per strain. The NTSYS software (version 1.7) was employed for data processing, using three association coefficients [Jaccard, Dice and Simple Matching (SM)] and the UPGMA (unweighted pair-group method using arithmetic averages) clustering algorithm. This was followed by the construction of phenograms, which represented the global similarity among the stocks analyzed.

\section{RESULTS AND DISCUSSION}

In our experimental conditions, complex protein patterns were found in all $T$. cruzi stocks analyzed by SDS-PAGE, each one displaying more than 40 protein bands. All isolates shared $25 \%$ of these bands (conserved proteins), including those with molecular mass compatible to heat shock proteins (HSPs) and the glycoprotein gp63 (Fig. 1). All stocks displayed bands varying between $>170-17 \mathrm{kDa}$, the more prominent ones ranging from $\sim 95-72 \mathrm{kDa},>55-34 \mathrm{kDa}$, and $17 \mathrm{kDa}$. They appear typical of $T$. cruzi, since they were also found in other studies (Taylor et al. 1983, CervantesLandín et al. 2014). Otherwise, nearly 55\% of the protein bands were not shared by all stocks (non-conserved proteins), thus being the most useful data to analyze the intra-specific variability in $T$. cruzi. These proteins were lightly stained, but could be visualized and were coded for numerical analysis. They are diagrammatically represented in Fig. 2, where those bands exclusive of some strains were also highlighted with rectangles.

Trypanosoma cruzi SDS-PAGE banding patterns of the present study could not be easily correlated with those from other studies, where whole-cell proteins of epimastigotes from axenic cultures of this species were analyzed (Taylor et al. 1983, Barr et al. 1990, Mejía et al. 2004). This probably was due to operational differences, such as the polyacrylamide concentrations, electrophoretic running conditions and gel sizes, since they could affect the resolution of the protein bands, as previously observed (Taylor et al. 1982). However, we 
could identify several conserved proteins of $T$. cruzi, as seen in our SDS-PAGE analysis, in the gels from the study of Cervantes-Landín et al. (2014).

The "deme" terminology was proposed by Hoare (1967) to be used as name suffix of subgroups within a species or subspecies, according to any chosen criterion (e.g. zymodeme, schizodeme). Taylor et al. (1982) proposed the name "peptideme" for grouping species of Trypanosoma (Schizotrypanum) from bats based on the visualization of some distinctive proteins in SDSPAGE, then describing eight peptidemes. However, in that study, distinct species were placed into a same peptideme, whereas strains of a same species were classified into distinct peptidemes. Subsequently, Taylor et al. (1983) also analyzed three $T$. cruzi reference stocks from distinct zymodemes (Z1, Z2 and Z3, currently corresponding to TcI, TcII and TcIV) by SDS-PAGE. They obtained an excellent gel (see p. 357) in which some protein bands perfectly distinguish those stocks, probably being of diagnostic value. In the same study, the authors analyzed thirty-six $T$. cruzi isolates whose zymodeme had been previously determined, only one being reference stock (TcI), and proposed their classification into five peptidemes. However, the dispersion of the zymodemes within each peptideme remained barely understandable. This was probably due to the visual choice of the set of protein bands used to delimit each peptideme, besides the use of a single reference strain.

Aiming to a better understanding of the complex banding patterns generated by SDS-PAGE in $T$. cruzi (Fig. 1), we used a more objective procedure for grouping the stocks analyzed in the present study, as that provided by numerical taxonomy (Sneath and Sokal 1962). It is worthy mentioning that the numerical taxonomy has been successfully used following SDS-PAGE, mainly with bacteria and fungi, disclosing reliable groupings (Costas 1990, Rosa et al. 2000, Rodrigues et al. 2004).

In the present work, using the three association coefficients, the UPGMA phenograms displayed two major groups of strains in $T$. cruzi, which were identified herein as major peptidemes, and referred as $\mathbf{m P} \mathbf{1}$ and mP 2 (Fig. 3). This confirmed the dichotomy within the T. cruzi taxon, as previously reported by several authors (Tibayrenc et al. 1993, Souto et al. 1996, Brisse et al. 2000). The numbering of these major peptidemes followed that used by Brisse et al. (2000) for the two major T. cruzi lineages (1 and 2) (Figs 2, 3). Both $\mathbf{m P} 1$ and mP 2 also presented subgroups, these herein referred simply as peptidemes (P), also confirming the diver- sity within each major $T$. cruzi lineage (Tibayrenc et al. 1993, Brisse et al. 2000).

In our study, the $\mathbf{m P} \mathbf{1}$ only included strains identified as TcI (formerly DTU 1, Z1). However, using the SM coefficient, which considers positive and negative matches, a clear subdivision was observed (Fig. 3). One of them only included isolates from opossums ( $\mathrm{G}, \mathrm{SC} 28$, $\mathrm{Dm} 28 \mathrm{c}$ ), remaining apart a strain of human origin from Colombian. In the last decade, studies with different molecular markers showed a remarkable genetic diversity within TcI. Several authors proposed its subdivision into five subtypes, identified as TcIa-TcIe, whereas others recommended to group them only in two genotypes, one being domestic (identified as $\mathrm{Tc}_{\mathrm{DOM}}$ ) and the other sylvatic (León et al. 2015). However, at present, no consensual nomenclature for the TcI subtypes was defined (Ramírez and Hernández 2018). Therefore, in the present study, all strains from the $\mathbf{m P} \mathbf{1}$ remained classified into a single peptideme, herein identified as $\mathbf{P} \mathbf{I}$.

As illustrated in Fig. 3, mP 2 displayed two well distinct subgroups/peptidemes $(\mathbf{P})$, regardless the association coefficients used. One of them, herein identified as P II, included two strains of human origin from Brazil (Y and SF21), both previously classified as TcII (formerly DTU 2b, Z2). The other, identified as P VI, presented two stocks from triatomine bugs from Southern Brazil (CL Brener and FL), both belonging to TcVI (formerly DTU 2e, ZB). It is worthy mentioning that to avoid confused interpretations, the numbering of the peptidemes described in the present work (P I, P II, $\mathbf{P}$ VI) is the same of their genetic types (TcI, TcII and TcVI), as consensually defined (Zingales et al. 2009).

\section{CONCLUSIONS}

Our study indicates that the analysis of non-conserved proteins of T. cruzi stocks, as seen in SDS-PAGE and treated by numerical taxonomy procedures, can arise consistent intra-specific classifications, as reported for other microorganisms (e.g. Costas 1990, Rosa et al. 2000, Rodrigues et al. 2004). It was evidenced that $T$. cruzi strains belonging to the same genetic type (formerly DTU, zymodeme) were clustered, in a parallel manner, into a same peptideme. This demonstrates that the protein profiles from SDS-PAGE are also bona fide markers, as the isoenzymes, which provided the pioneering identification of the six T. cruzi lineages (Tibayrenc and Ayala 1988, Brisse et al. 2000), then 


\section{Trypanosoma cruzi reference strains}

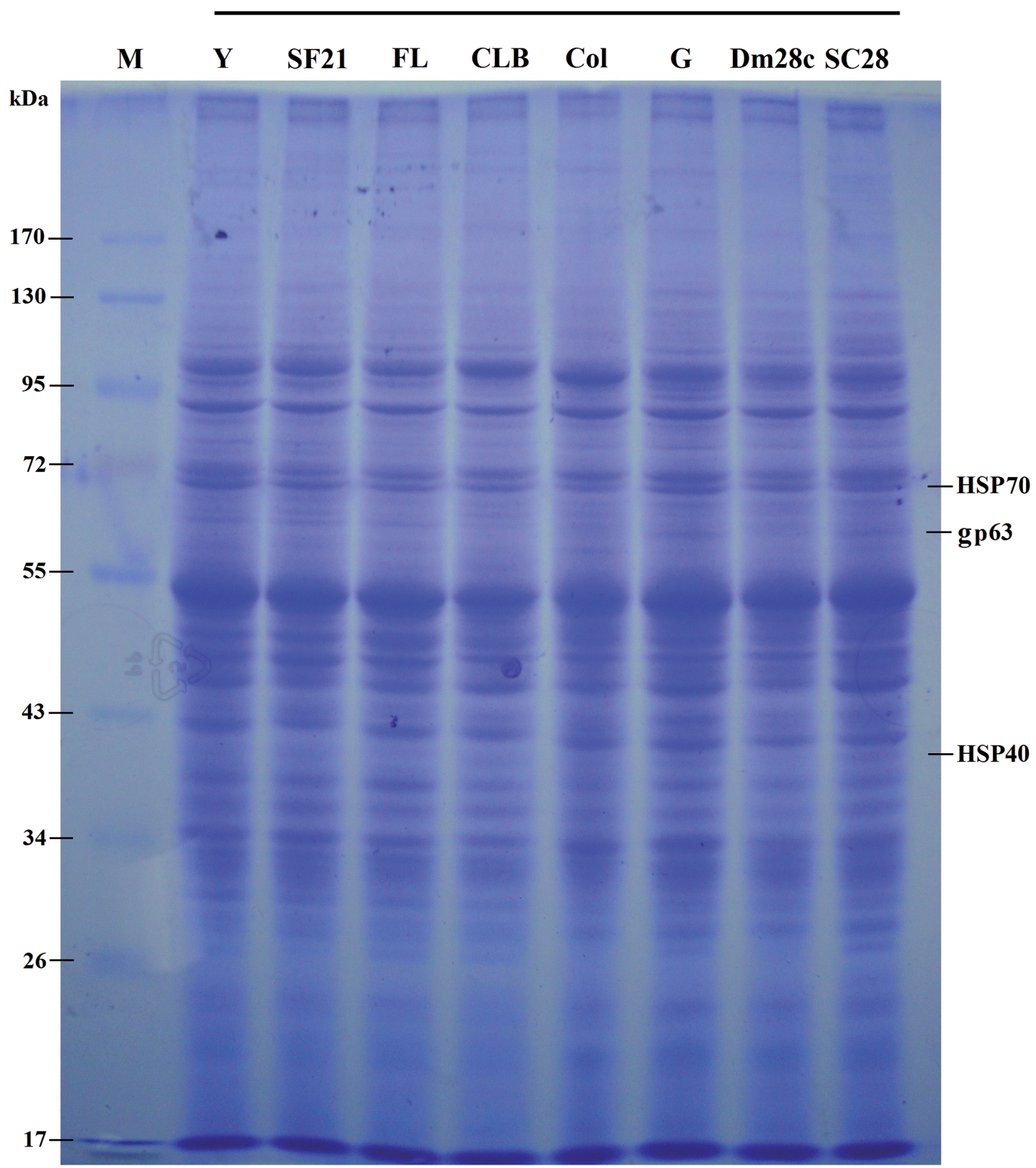

Fig. 1. Total protein profiles of eight Trypanosoma cruzi reference strains separated in 10\% SDS-PAGE at $250 \mathrm{~V}, 25 \mathrm{~mA}, 90 \mathrm{~min}$, and stained by Coomassie brilliant blue. The position of some conserved proteins is indicated on the right. M: molecular mass markers. (kDa) are indicated on the left. 
Trypanosoma cruzi reference strains: major peptidemes
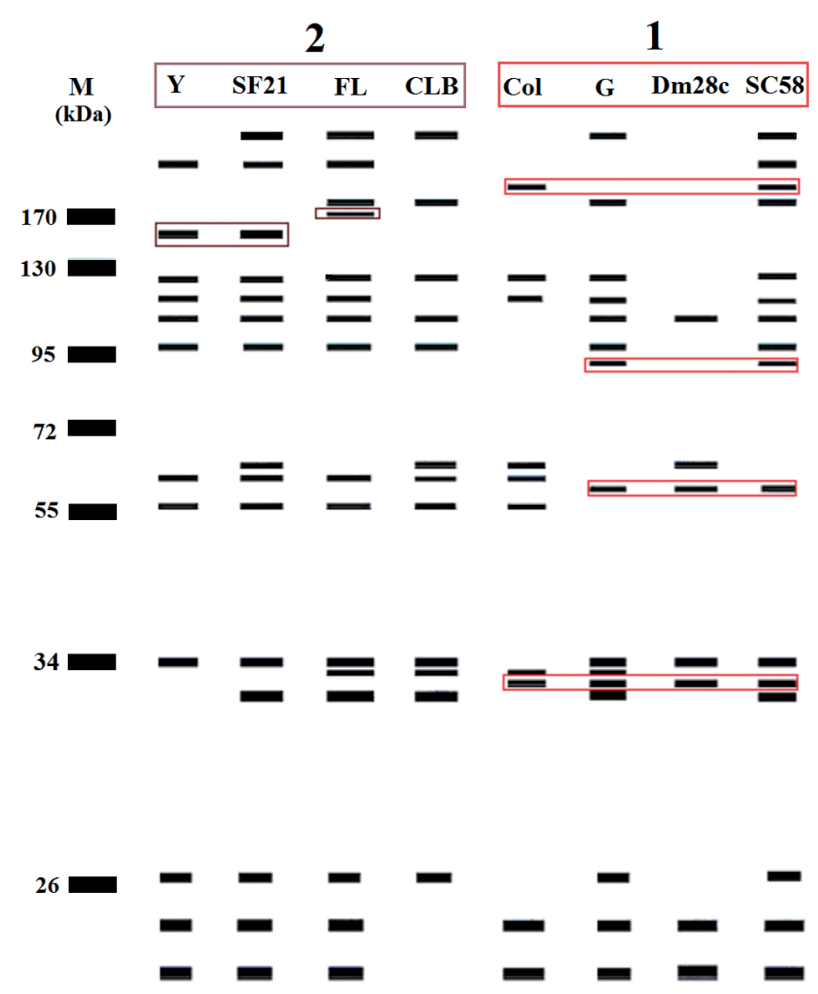

Fig. 2. Diagrammatic representation of the twenty-two protein bands not shared by all Trypanosoma cruzi reference strains (nonconserved proteins), as visualized in SDS-PAGE. These bands were coded and analyzed by numerical taxonomy procedures. At the top is indicated the number of the major groups they belong, as identified by different approaches. The bands that were exclusive of one or more strains were highlighted with rectangles. M: molecular mass markers. (kDa) are indicated on the left.

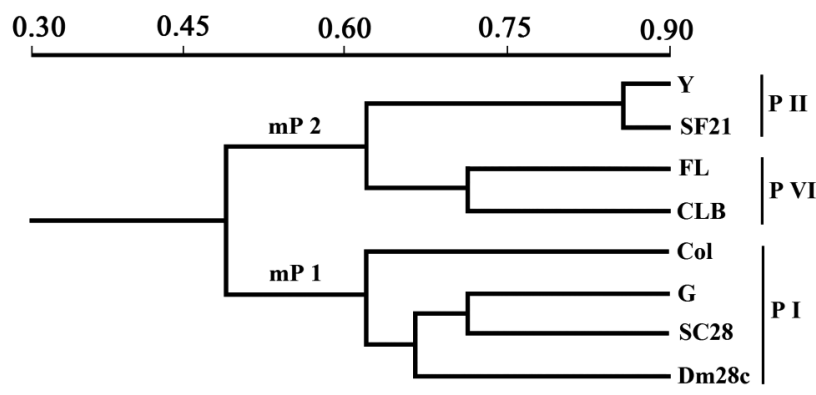

Fig. 3. Phenogram of the peptidemes (P) of eight Trypanosoma cruzi reference strains obtained using the SM coefficient and the UPGMA clustering algorithm, based on data from non-conserved proteins, as seen in SDS-PAGE analysis. The major peptidemes are indicated as $\mathbf{m P} \mathbf{1}$ and $\mathbf{m P} \mathbf{2}$. Their subgroups are identified on the right (P II, P VI, P I), and were numbered following their respective genetic types (TcII, TcVI, TcI), as currently used. evidencing correlations between phenotypes and genotypes. Accordingly, we suggest that the present study be expanded to include analyses of a larger number of T. cruzi reference strains with distinct genotypes, as well as other Trypanosoma species, mainly to identify protein bands with diagnostic value. Finally, considering that SDS-PAGE analysis has low cost, fast and easy execution, using a single gel, it can be also used as a simple alternative technique for routine controlling of the authenticity of trypanosomatids maintained in cultures, since the procedure can be performed under rigorously standardized conditions.

\section{REFERENCES}

Andrade S. G. (1974) Caracterização de cepas do Trypanosoma cruzi isoladas no Recôncavo Baiano. Rev. Pat. Trop. 3: 65-121

Añez-Rojas N., Garcia-Lugo P., Crisante G., Rojas A., Añez N. (2006) Isolation, purification and characterization of GPIanchored membrane proteins from Trypanosoma rangeli and Trypanosoma cruzi. Acta Trop. 97: 140-145

Avila C. C., Almeida F. G., Palmisano G. ( 2016) Direct identificaton of trypanosomatids by matrix-assisted laser desorption ionization-time of flight mass spectrometria (DIT MALDITOF MS). J. Mass Spectrom. 51: 549-557 (doi: org/10.1002/ jms3763)

Barr S. C., Dennis V. A., Klei T. R. (1990) Growth characteristics in axenic and cell cultures, protein profiles, and zymodeme typing of three Trypanosoma cruzi isolates from Louisiana mammals. J. Parasitol. 76: 631-638

Branquinha M. H., Meirelles M. N. L., Lopes A., Moreira C., Vermelho A. B. (1995) Use of glycoconjugates for trypanosomatid taxonomy. Curr. Microbiol. 30: 77-82

Brener Z. (1965) Comparative studies of different strains of Trypanosma cruzi. Ann. Trop. Med. Parasitol. 59: 19-26

Brisse S., Barnabé C., Tibayrenc M. (2000) Identification of six Trypanosoma cruzi phylogenetic lineages by random amplified polymorphic DNA and multilocus enzyme electrophoresis. Int. J. Parasitol. 30: 35-44

Cervantes-Landín A. Y., Martinez I., Schabib M., Espinoza B. (2014) High molecular weight proteins proteins of Trypanosoma cruzi reduce cross-reaction with Leishmania spp. in serological diagnosis tests. BioMed. Res. Int: https//dx.doi. org/10.1155/2014/365403

Contreras V. T., Salles J. M., Thomas N., Morel C. M., Goldenberg S. (1985) In vitro differentiation of Trypanosoma cruzi under chemically defined conditions. Mol. Biochem. Parasitol. 16: 315-327

Cosentino R. O., Agüero F. (2012) A simple strain typing assay for Trypanosoma cruzi: discrimination of major evolutionary lineages from a single amplification product. PLoS Negl. Trop. Dis. 6(7): e 1777

Costas M. (1990) Numerical analysis of sodium dodecyl sulphatepolycrylamide gel electrophoretic protein patterns for the classification, identification and typing of medically important bacteria. Electrophoresis 11: 382-391

Cura C. I., Duffy T., Lucero R. H., Bisio M., Péneau J., JimenezCoello M., Calabuig E., Gimenez M. J., Valencia Ayala E., Kjos S. A., Santalla J., Mahaney S. M., Cayo N. M., Nagel 
C., Barcán L., Machaca E. S. M., Acosta Viana K.Y., Brutus L., Ocampo S. B., Aznar C., Cuba-Cuba C. A., Gürtler R. E., Ramsey J. M., Ribeiro I., VandeBerg J. L., Yadon Z. E., Osuna A., Schijman A. G. (2015) Multiplex real-time PCR assay using TaqMan probes for the identification of Trypanosoma cruzi DTUs in biological and clinical samples. PLoS Negl. Trop. Dis. 9(5): e0003765

El- Sayed N. M., Myler P. J., Blandin G., Berriman M., Crabtree J., Aggarwal G., Caler E., Renauld H., Worthey E. A., HertzFowler C., Ghedin E., Peacock C., Bartholomeu D. C., Hass B. J., Tran A.-N., Wortman J. R., Alsmark U. C. M., Angiuoli S., Anupama A., Badger J., Bringaud F., Cadag E., Carlton J. M., Cerqueira G. C., Creasy T., Delcher A. L., Djikeng A., Embley T. M., Hause C., Ivens A. C., Kummerfeld S. K., Pereira-Leal J. B., Nilsson D., Peterson J., Salzberg S. L., Shallom J., Silva J. C., Sandaram J., Westenberger S., White O., Melville S. E., Donelson J. E., Andersson B., Stuart K. D., Hall N. (2005) Comparative genomics of trypanosomatid parasitic protozoa. Science 309: 404-409

Fernandes O., Santos S. S., Cupolillo E., Mendonça B., Derre R., Junqueira A. C. V., Santos L. C., Sturm N. R., Naiff R. D., Barret T. V., Campbell D. A., Coura J. R. (2001) A mini-exon multiplex polymerase chain reaction to distinguish the major groups of Trypanosoma cruzi and T. rangeli in the Brazilian Amazon. Trans. R. Soc. Trop. Med. Hyg. 95: 97-99

Gibson W. C., Parr C. W., Swindlehurst C. A., Welch S. G. (1978) A comparison of the isoenzymes, soluble proteins, polypeptides and free amino acids from ten isolates of Trypanosoma evansi. Comp. Biochem. Physiol. 60B: 137-142

Gomes S. A. O., Misael D., Silva B., Feder D., Silva C. S., MonteGonçalves T. C., Santos A. L. S., Santos-Mallet J. R. (2009). Major cysteine protease (cruzipain) in Z3 sylvatic isolates of Trypanosoma cruzi from Rio de Janeiro, Brazil. Parasitol. Res. 105: $743-749$

Hoare C. A. (1967) Evolutionary trends in mammalian trypanosomes. Adv. Parasitol. 5: 47-91

Janssen P. T., Van Bijsterveld O. P. (1981) Comparison of electrophoretic techniques for the analysis of human tear fluid proteins. Clin. Chim. Acta 114: 207-2018

Kikuchi A. S., Sodré C. L., Kalume D. E., Elias E. G. R., Santos A. L. S., Soeiro M. N., Meuser M., Chapeaurouge A., Perales J., Fernandes O. (2010). Proteomic analysis of two Trypanosoma cruzi zymodeme 3 strains. Exp. Parasitol. 126: 540-551

Laemmli U. K. (1970) Cleavage of structural proteins during the assembly of the head of bacteriophage T4. Nature 277: 680-685

León C. M., Hernández C., Montilla M., Ramirez J. D. (2015) Retrospective distribution of Trypanosoma cruzi I genotypes in Colombia. Mem. Inst. Oswaldo Cruz 110: 378-393

Lima L., Espinosa-Álvarez O., Ortiz P. A., Trejo-Varón J. A., Carranza J. C., Pinto C. M., Serrano M. G., Buck G. A., Camargo E. P., Teixeira M. M. G. (2015) Genetic diversity of Trypanosoma cruzi in bats, and multilocus phylogenetic and phylogeographical analyses supporting Tcbat as an independent DTU (discrete typing units). Acta Trop. 151: 166-177

Lowry O. H., Rosebrough N. J., Farr A. L., Randall R. J. (1951) Protein measurement with the Folin phenol reagent. J. Biol. Chem. 193: $265-275$

Luna-Marín K. P., Jaramillo-Londoño C. L., Hérnandez-Torres J., Gutiérrez-Marín R., Vallejo G. A., Angulo-Silva V. M. (2009) ITS-RFLP- and RAPD-based genetic variability of Trypanosoma cruzi I, human and vector strains in Santander (Colombia). Parasitol. Res. 105: 519-528
Macedo A. M., Vallejo G. A., Chiari E., Pena D. J. (1993) DNA fingerprinting reveals relationships between strains of Trypanosoma rangeli and Trypanosoma cruzi. In: DNA Fingerprinting: State of Science, (Eds. S. D. J. Pena, R. Chakraborty, J. T. Epplan, A. J. Jeffreys). Birkäuser Verlag Basel, 321-329

Marcili A., Lima L., Cavazzana Jr M., Junqueira A. C. V., Veludo H. H., Maia-da-Silva F., Campaner M., Paiva F., Nunes V. L. B., Teixeira M. M. G. (2009) A new genotype of Trypanosoma cruzi associated with bats evidenced by phylogenetic analyses using SSU rDNA, cytochrome $\mathrm{b}$ and Histone H2B genes and genotyping based on ITS1 rDNA. Parasitology 136: 641-655

Mejía A. J., Paláu M. T., Züñiga C. A. (2004) Protein profiles of Trypanosoma cruzi and Trypanosoma rangeli. Parasitol. Latinoam. 59: 142-147

Miles M. A., Souza A., Póvoa M., Shaw J. J., Lainson R., Toyé P. J. (1978) Isozymic heterogeneity of Trypanosoma cruzi in the first autochthonous patients with Chagas' disease in Amazonian Brazil. Nature 272: 819-821

Moraes M. H., Guarneri A., Girardi F., Rodrigues J. B., Eger I., Tyler K. M., Steindel M., Grisard E. C. (2008) Different serological cross-reactivity of Trypanosoma rangeli forms in Trypanosoma cruzi-infected patients sera. Parasit Vectors: https//doi. org/10.1186/1756-3305-1-20

Morel C., Chiari E., Camargo E. A., Mattei D. M., Romanha A. J., Simpson L. (1980) Strains and clones of Trypanosoma cruzi can be characterized by pattern of restriction endonuclease. Proc. Natl Acad. Sci. (USA) 77: 6810-6814

Oliveira G. S., Kawahara R., Rosa-Fernandes L., Mule S. N., Avila C. C., Teixeira M. M. G., Larsen M. R., Palmisano G. (2018) Development of a Trypanosoma cruzi strain typing assay using MS2 peptide spectral libraries (Tc-STAMS2). PLoS Negl. Trop. Dis. 12(4): e0006351

Oliveira T. S. F., Santos B. N., Galdino T. S., Hasslocher-Moreno A. M., Bastos O. M. P., Sousa M. A. (2017) Trypanosoma cruzi I among isolates from chronic Chagas disease patients followed at the Evandro Chagas National Institute of Infectious Diseases (Fiocruz, Brazil). Rev. Soc. Brasil. Med. Trop. 50: 35-43

Pinho R. T., Giovanni-de-Simone S. (1989) Characterization of plasma membrane polypeptides of Trypanosoma from bats. Mem. Inst. Oswaldo Cruz 84: 13-18

Ramírez J. D., Hernández C. (2018) Trypanosoma cruzi I: towards the need of genetic subdivision? Part II. Acta Trop. 184: 53-58

Rodrigues C. C., Höfling J. F., Boriollo M. F. G., Rodrigues J. A. O., Azevedo R. A., Gonçalves R. B., Gomes L. H., Tavares F. C. A. (2004) SDS-PAGE and numerical analysis of Candida albicans from human oral cavity and other anatomical sites. Braz. J. Microbiol. 35: 40-47

Rosa E. A. R., Rosa R. T., Pereira C. V., Boriollo M. F. G., Höfling J. F. (2000) Analysis of parity between protein-based electrophoretic methods for the characterization of oral Candida species. Mem. Inst. Oswaldo Cruz 95: 801-806

Saldaña A., Harris R. A., Örn A., Sousa O. E. (1998) Trypanosoma rangeli: identification and purification of a $48-\mathrm{kDa}$-specific antigen. J. Parasitol. 84: 67-73

Saldaña A., Örn A., Henriksson J., Sousa O. E. (1993) Evaluacion de cuatro metodos immunobioquimico/moleculares en la identificacion de cepas de Trypanosoma cruzi y Trypanosoma rangeli. Rev. Med. Panamá 18: 41-52

Sneath P. H. A., Sokal R. R. (1962) Numerical taxonomy. Nature 193: $855-860$

Sousa M. A. (1999) Morphobiological characterization of Trypanosoma cruzi Chagas, 1909 and its distinction from other trypanosomes. Mem. Inst. Oswaldo Cruz 94 (Suppl I): 205-210 
Souto R. P., Fernandes O., Macedo A. M., Campbell D. A., Zingales B. (1996) DNA markers define two major phylogenetic lineages of Trypanosoma cruzi. Mol. Biochem. Parasitol. 83: 141-152

Sturm N. R., Degrave W., Morel C., Simpson L. (1989) Sensitive detection and schizodeme classification of Trypanosoma cruzi cells by amplification of kinetoplast minicircle DNA sequences: use in diagnosis of Chagas' disease. Mol. Biochem. Parasitol. 33: $205-214$

Tanowitz H. B., Weiss L. M., Montgomery S. P. (2011) Chagas disease has now gone global. PLoS Negl. Trop. Dis. 5(4): e1136

Taylor A. E. R., Edwards Y. H., Smith V., Baker J. R., Woo P. T. K., Lanham S. M., Pennick N. C. (1982) Trypanosoma (Schizotrypanum) species from insectivorous bats (Microchiroptera): characterization by polypeptide profiles. Syst. Parasitol. 4: 155-168

Taylor A. E. R., Edwards Y. H., Smith V., Miles M. A., Gibson W. C. (1983) The polypeptide profiles of strains of the Trypanosoma subgenera Schizotrypanum and Trypanozoon: peptideme characterization. Trans. R. Soc. Trop. Med. Hyg. 77: 354-362

Taylor A. E. R., Williams J. E. (1977) The possibility of characterizing South American trypanosomes with sodium dodecyl sulphate polyacrylamide gel electrophoresis. Parasitology 75: 23

Tibayrenc M., Neubauer K., Barnabé C., Guerrini F., Skarecky D., Ayala F. J. (1993) Genetic characterization of six parasitic Protozoa: parity between random-primer DNA typing and multilocus enzyme electrophoresis. Proc. Natl Acad. Sci. (USA) 90: 1335-1339
Tibayrenc M., Ayala F. J. (1988) Isozyme variability in Trypanosoma cruzi, the agent of Chagas' disease: genetical, taxonomical, and epidemiological significance. Evolution 42: 277-292

WHO (2019) Chagas disease (American Trypanosomiasis). https:// www.who.int/news-room/fact-sheets/detail/chagas-disease(american-trypanosomiasis)

Ziccardi M., Lourenço-de-Oliveira R., Alves M. C., Cruz M. F. F. (2005) Trypanosoma saimirii Rodhain, a junior synonym of Trypanosoma rangeli Tejera. J. Parasitol. 91: 653-656

Zingales B., Andrade S. G., Briones M. R. S., Campbell D. A., Chiari E., Fernandes O., Guhl F., Lages-Silva E., Macedo A. M., Machado C. R., Miles M. A., Romanha A. J., Sturm N. R., Tibayrenc M., Schijman A. G. (2009) A new consensus for Trypanosoma cruzi intraspecific nomenclature: second revision meeting recommends TcI to TcVI. Mem. Inst. Oswaldo Cruz 104: 1051-1054

Zingales B., Miles M. A., Campbell D. A., Tibayrenc M., Macedo A. M., Teixeira M. M. G., Schijman A. G., Llewellyn M. S., Lages-Silva E., Machado C. R., Andrade S. G., Sturm N. R. (2012) The revised Trypanosoma cruzi subspecific nomenclature: rationale, epidemiological relevance and research applications. Infect. Genet. Evol. 12: 240-253

Received on $1^{\text {st }}$ June, 2019; revised on $25^{\text {th }}$ September, 2019; accepted on $4^{\text {th }}$ November, 2019 